\title{
PERBEDAAN SPESIFIC VALUES ANTARA MAHASISWA AKUNTANSI, MANAJEMEN, DAN EKONOMI PEMBANGUNAN : STUDI EMPIRIS PADA UNIVERSITAS PATTIMURA
}

\section{THE DIFFERENCE OF SPECIFIC VALUES BETWEEN ACCOUNTING, MANAGEMENT, AND ECONOMIC STUDENTS: DEVELOPMENT OF EMPIRICAL STUDIES IN PATTIMURA UNIVERSITY}

\author{
Oleh: \\ Trisna Sary Lewaru \\ Universitas Pattimura, Ambon \\ eka_lewa@yahoo.com \\ Fanny M. Anakotta \\ Universitas Pattimura, Ambon \\ monicfanny@gmail.com
}

\begin{abstract}
Abstrak
Penelitian ini bertujuan untuk menganalisis perbedaan specific value antara mahasiswa akuntansi, mahasiswa manajemen, mahasiswa ekonomi pembangunan. Pengumpulan data dilakukan dengan menyebarkan kuesioner. Sampel dalam penelitian ini adalah mahasiswa akuntansi, manajemen, dan ekonomi pembangunan yang terdaftar di Fakultas Ekonomi Universitas Pattimura. Tekhnik pengambilan sampelnya menggunakan purposive sampling. Pengujian hipotesis dilakukan dengan menggunakan One Way ANOVA. Hasil penelitian ini menunjukan bahwa terdapat perbedaan specific value yang signifikan dalam nilai individualitas, sosial, teoretis, estetis antara mahasiswa akuntansi, manajemen, dan Ekonomi Pembangunan
\end{abstract}

Keywords : etika, spesific values, individualitas, sosial, teoretis, estetis

\begin{abstract}
This study aims to analyze, to compare and to differentiate specific values of accounting, management, development economic. Data collection is done by distributing questionnaires. The sample in this studies accounting, management, and development economics students registered at the Faculty of Economics, Pattimura University. The sampling technique uses purposive sampling. Hypothesis testing is done using One Way ANOVA. The study shows that there are significant differences of specific value in the value of indivualis, theoretical, social, and esthetical, among accounting, management, development economic students.
\end{abstract}

Keywords : ethics, spesific values, individuality, theoretical, social, aesthetics 


\section{PENDAHULUAN}

Perguruan tinggi merupakan salah satu tempat untuk mencari prioritas nilai-nilai seseorang, dan pendidikan sangat berkaitan dengan nilai prestasi (Schwartz, 2010, dalam Diahsari 2011). Berdasarkan observasi, kecenderungan prioritas nilai-nilai yang dimiliki mahasiswa tahun 60-an sampai 2004 adalah pencapaian kondisi finansial yang baik, namun demikian, nilai-nilai yang juga masih cukup penting bagi mereka adalah memikirkan kesejahteraan orang lain (Santrock, 2007). Hal tersebut menunjukkan bahwa kehidupan kampus yang dinamis dapat menyediakan kesempatan bagi mahasiswa untuk mengembangkan berbagai macam nilai-nilai hidup melalui interaksi sosial. Nilai yang dimiliki dan dikembangkan ini dapat diekspresikan dalam beberapa bentuk, termasuk dalam bentuk disposisi kepribadian, sehingga kepribadian yang berbeda dimungkinkan memiliki orientasi nilai yang berbeda pula (Cileli \& Tezer, dalam Diahsari, 2011).

Mahasiswa sebagai calon profesional dimasa mendatang perlu dibekali materi pembentukan karaketer seorang profesional, disamping pengetahuan dan keahlian yang relevan dengan bidang konsentrasinya masing-masing. Hal ini dikarenakan setiap mahasiswa memiliki nilai personal yang berbeda. Perbedaan ini disebabkan oleh kondisi ekonomi, sosial, politik, dan budaya yang berbeda. Begitupun Lingkungan dimana mereka berada, menurut penelitian Manan (2019) faktor dari menurunnya etika dari mahasiswa disebabkan faktor eksternal seperti pengaruh dari lingkungan keluarga, lingkungan masyarakat dan lingkungan sosial serta pengaruh globalisasi. dan Era globalisasi saat ini sudah tidak dapat dihindari dalam kehidupan masyarakat, khususnya kaum muda, termasuk didalamnya mahasiswa yang merupakan salah satu sasaran strategis terjadinya degrasi moral dan etika. Seiring dengan berjalannya waktu, mahasiswa mulai mengabaikan etika sopan santun yang sudah mengakar kuat dalam masyarakat. Lingkungan akademik maupun lingkungan pergaulan menjadi faktor terkikis nilai-nilai etika dan kesopanan mahasisa dalam berperilaku di masyarakat maupun dikampus.

Penelitian mengenai specific values di Indonesia masih sangat sedikit. Padahal penelitian mengenai nilai-nilai personal mahasiswa ini sangat penting karena nilai-nilai personal mahasiswa memberikan masukan terhadap program pendidikan di perguruan tinggi dan mahasiswa mewakili kelompok calon pemimpin sebuah organisasi di masa yang akan datang (Fathonah, 2004). Hal ini lah yang mendorong peneliti untuk meneliti lebih lanjut terkait dengan Specifid value. Dilain pihak, seperti diketahui bahwa ketiga jurusan yang dijadikan sampel hanya satu jurusan yaitu Jurusan Akutansi yang memiliki ikatan profesi sedangkan kedua jurusan lainnya yaitu Jurusan Manajemen dan Ekonomi Pembangunan tidak memiliki ikatan profesi, sehingga menjadi menarik untuk diteliti lebih lanjut.

Etika berasal dari bahasa Yunani yaitu ethos yang berarti watak kesusilaan atau adat. Dalam Kamus Umum Bahasa Indonesia, etika memiliki arti ilmu pengetahuan tentang asasasas akhlak (moral). Dengan begitu, etika juga memiliki hubungan dengan upaya menentukan tingkah laku manusia (Muslimah, 2016). Dimana Etika meliputi suatu proses penentuan yang kompleks tentang apa yang harus dilakukan seseorang dalam situasi tertentu. Proses tersebut meliputi penyeimbangan sifat sisi dalam (inner) dan sisi luar (outler) yang dibentuk oleh kombinasi unik dari pengalaman dan pembelajaran masing -masing individu (Dewi,2019).

Pengertian etika juga dikemukakan oleh Ki Hajar Dewantara, bahwa etika adalah ilmu yang mempelajari soal kebaikan dan keburukan di dalam hidup manusia semuanya, terutama yang mengenai gerak-gerik pikiran dan rasa yang merupakan pertimbangan dan perasaan, sehingga dapat mencapai tujuannya dalam bentuk perbuatan (Muslimah, 2016). Sedangkan menurut Soegarda Poerbakawatja, etika adalah filsafat nilai, pengetahuan tentang nilai-nilai, ilmu yang mempelajari soal kebaikan dan keburukan di dalam hidup manusia semuanya, 
terutama mengenai gerak gerik pikiran dan rasa yang merupakan pertimbangan dan perasaan sampai mengenai tujuannya bentu perbuatan (Muslimah, 2016). Dengan demikian etika dapat memperlihatkan pengetahuan tentang nilai-nilai yang dimiliki oleh seseorang. Nilai digunakan untuk mempresentasikan tujuan-tujuan secara mental dan disampaikan melalui interaksi sosial (Schwartz, 2012, dalam Fitriah, 2014).

Adapun personal values adalah konstruk motivasional yang ada dalam diri seseorang dan dapat mempengaruhi tingkah laku sosial orang tersebut terhadap orang-orang disekitarnya. Schwartz berpandangan bahwa nilai merupakan representasi kognitif dari tiga tipe persyaratan hidup manusia yang universal, yaitu: 1) kebutuhan individu sebagai organisme biologis, 2) interaksi sosial yang membutuhkan koordinasi interpersonal, 3) tuntutan institusi sosial untuk mencapai kesejahteraan kelompok dan kelangsungan hidup kelompok (Schwartz, 2012 dalam Fitriah, 2014). Rokeach (1968, dalam Giacomino dan Akers, 1998) mendefinisikan personal values sebagai berikut: "To say that a person has a values is to say that he has an enduring belief that a specisic model of cunduct or end state of existence is personally and socially preferable to alternative modes of conduct or end state of existence". Specific values adalah nilai yang secara khusus membedakan perilaku manusia, dalam hal ini mahasiswa, dimana specific values meliputi value individualitas, value teoritis, value sosial, dan value estetis, dan merupakan konstruk dari personal value yang sangat berkaitan erat (Fathonah, 2004). Tabel dibawah ini menggambarkan konstruk dan elemen pengukurnya.

\section{Tabel 1 \\ Konstruk dan Elemen Pengukuran}

\begin{tabular}{lll}
\hline \multicolumn{1}{c}{ Konstruk } & \multicolumn{1}{c}{ Elemen Pengukur } \\
\hline 1. Individualitas & Capable & Honest \\
& Self-respect & Responsible \\
& Ambitious & Independent \\
& Successful & Meaning in life \\
& Healthy & Wealth \\
& Inner harmony & \\
\hline 2. Sosial & Self discipline & National security \\
& Family security & True friendship \\
& Wisdom & Enjoying \\
& Equality & Freedom \\
\hline 3. Teoretis & Obedient & Forgiving \\
& Clean & Broadminded \\
& Helpful & Loyal \\
& Intelligent & Moderate \\
& Mature love & Curious \\
& Creativity & a world of beauty \\
\hline 4. Estetis & &
\end{tabular}

Sumber: Fathonah, 2004

Keempat konstruk diatas dideskripsikan sebagai berikut: seseorang yang individualis mempunyai karakteristik sebagai berikut: mampu untuk berkompeten dengan cara yang efisien dan efektif (capable); percaya pada diri sendiri (self-respect); suka bekerja keras dan bercita-cita tinggi (ambitious); berprestasi dan bisa mencapai tujuan (successful); mampu menjaga kesehatan mental dan fisik (healthy); mampu untuk bertindak secara jujur, ikhlas dan tulus hati (honest); bisa dipercaya dan diandalkan (responsible); percaya diri dan tidak tergantung pada orang lain (independent); dan mampu untuk menentukan tujuan hidupnya 
sendiri (meaning in life). Seseorang yang sosial dicirikan sebagai berikut: tahan terhadap segala macam godaan (self-discipline); lebih mencintai orang lain (family security); pemahaman yang dewasa tentang hidup (wisdom); peduli dengan kondisi negaranya (national security); dan lebih suka bersahabat dengan banyak orang (true friendship).

Seseorang yang teoretis dikarakteristikkan sebagai berikut: lebih mementingkan kewajiban dibanding hak (obedient); lebih mementingkan kebersihan, kerapian, keteraturan (clean), lebih suka bekerja untuk kepentingan orang banyak (helpful); sangat menyukai untuk berfikir secara logis (intelligent); lebih bersedia untuk memaafkan kesalahan orang lain (forgiving); berpikiran luas dan toleran dengan ide dan kepercayaan orang lain (broadminded); setia kepada teman dan kelompok (loyal); dan menghindari tindakan dan perasaan yang ekstrim (moderate). Seseorang yang estetis ditunjukkan dengan perasaannya yang mendalam (mature love); lebih menyukai sesuatu yang unik serta lebih suka untuk berimajinasi (creativity); lebih suka menyelidiki dan lebih mudah tertarik dengan sesuatu hal yang baru (curious); serta lebih menyukai keindahan alam dan kesenian (a world of beauty).

Sebagian besar penelitian yang berfokus pada value of accounting menggunakan instrumen yang diciptakan oleh Rokeach. Instrumen yang digunakan oleh Schwartz untuk mengukur personal value terlalu umum, sehingga inilah yang menyebabkan kelemahan penelitian yang dilakukan Schwartz. Fathonah (2004) juga menguji perbedaan spesific values antara mahasiswa akuntansi dan mahasiswa kedokteran pada Universitas gadjah mada dengan memodifikasikan instrumen Rokeach dan Schwartz. Fathonah menemukan bahwa ada perbedaan yang secara statistik signifikan antara mahasiswa akuntansi dan mahasiswa kedokteran dalan values spesifik mereka. Perbedaan itu terletak pada: value individualitas, value sosial, dan value teoretis. Tidak ada perbedaan yang secara signifikan antara mahasiswa akuntansi dan mahasiswa kedokteran dalam value estetis. Secara keseluruhan hasil penelitiannya menunjukan, personal values mahasiswa akuntansi lebih rendah dibandingkan dengan mahasiswa kedokteran. Padahal menurut Yusuf dan Anim (2015) menyatakan pekerjaan akuntan harus dilakukan dengan sikap profesional sepenuhnya berdasarkan standar modal dan etika yang berlaku. Oleh sebab itu sangat penting menumbuhkan perilaku etis para akuntan semenjak masih menjadi mahasiswa akuntansi.

Penelitian Specific values juga dilakukan oleh Suryaningsum, dkk (2005) dengan judul pentingnya perbandingan nilai-nilai spesifik antara mahasiswa akuntansi dan teknik sipil yang dilakukan pada beberapa perguruan tinggi di Yogyakarta. Hasil penelitiannya menemukan nilai individualitas, sosial, dan teoretis tidak ada perbedaan secara signifikan antara mahasiswa akuntansi dan teknik sipil. Hanya dalam hal nilai estetis mahasiswa akuntansi dan teknik sipil berbeda. Hal ini mungkin disebabkan karena mahasiswa akuntansi harus kreatif dalam menyelesaikan soal terutama berkaitan dengan analisis kasus. Di samping itu, mahasisa akuntansi memiliki waktu luang yang lebihh banyak sehingga dapat menikmati kesenian dan keindahan alam.

Proses pembelajaran di ketiga jurusan yang ada di fakultas ekonomi ini berbeda, oleh karena itu, hipotesis yang dapat diajukan adalah sebagai berikut :

Ho1 : Tidak terdapat perbedaan value individualitas antara mahasiswa akuntansi, manajemen, dan ekonomi pembangunan.

Ho2 : Tidak terdapat perbedaan value sosial antara mahasiswa akuntansi, manajemen, dan ekonomi pembangunan.

Ho3 : Tidak terdapat perbedaan value teoretis antara mahasiswa akuntansi, manajemen, dan ekonomi pembangunan.

Ho4 : Tidak terdapat perbedaan value estetis antara mahasiswa akuntansi, manajemen, dan ekonomi pembangunan. 


\section{METODE PENELITIAN}

\section{Jenis Penelitian}

Jenis penelitian ini adalah penelitian kausal komparatif dengan ex post facto atau penelitian yang dilakukan sesuai kenyataan yang ada dan tanpa adanya manipulasi, dimana peneliti berusaha menemukan pengaruh (sebab-akibat) dari suatu kejadian. Pendekatan yang digunakan adalah pendekatan kuantitatif.

\section{Populasi dan Sampel Penelitian}

Populasi dalam penelitian ini adalah Mahasiswa Fakultas Ekonomi dan Bisnis Universitas Pattimuran. Sedangkan sampel dalam penelitian ini adalah mahasiswa akuntansi, manajemen, dan ekonomi pembangunan yang telah menempuh mata kuliah MKDU dan yang telah mengambil mata kuliah yang mengandung muatan etika.

\section{Teknik Pengumpulan Data}

Tekhnik pengumpulan data yang digunakan adalah tekhnik survey untuk mendapatkan opini dan persepsi mahasiswa melalui penyebaran kuesioner di setiap jurusan yang diteliti.

\section{Instrumen Penelitian}

Instrumen yang digunakan dalam penelitian ini dikembangkan dari model Rokeach dan Schwartz yang diadaptasi oleh Fathonah (2004). Pertanyaaan dalam kuesioner merupakan instrumen values specific yang telah teruji realibilitas dan validitasnya.

\section{Teknik Analisis Data}

Sebelum melakukan analisis data, terlebih dahulu dilakukan uji normalitas dan uji homogenitas. Setelah memenuhi prasarat maka langkah selanjutnya adalah melakukan pengujian hipotesis menggunakan uji statistik One Way Anova .

\section{HASIL DAN PEMBAHASAN}

\section{A. Deskripsi Data}

Fakultas Ekonomi dan bisnis memiliki tiga Jurusan antara lain Akuntansi, Manajemen, Ekonomi Pembangunan. Ketiga jurusan ini memiliki perbedaan yang jelas jika dilihat dari mata kuliah keahlian (MKK), sedangkan untuk mata kuliah dasar umum (MKDU) sama untuk ketiganya. Berikut penjabarannya :

Tabel 2.

Daftar MKDU untuk Jurusan Akuntansi, Manajemen, Ekonomi Pembangunan

\begin{tabular}{clc}
\hline \multicolumn{1}{c}{ Program Studi } & \multicolumn{1}{c}{ MKDU } & Jumlah SKS \\
\hline Akuntansi & Agama & 2 \\
& Pancasila & 2 \\
& Kewiraan & 2 \\
& Ilmu Alamiah Dasar & 2 \\
Manajemen & Ilmu Budaya Dasar & 2 \\
& Agama & 2 \\
& Pancasila & 2 \\
& Kewiraan & 2 \\
& Ilmu Alamiah Dasar & 2 \\
& Ilmu Budaya Dasar & 2 \\
\hline
\end{tabular}


Jurnal Pendidikan Akuntansi Indonesia, Vol. 18, No. 1, Tahun 2020

Trisna Sari L. \& Fanny M. Anakotta

Hal. $12-19$

\begin{tabular}{clc}
\hline \hline & & \\
\hline Program Studi & \multicolumn{1}{c}{ MKDU } & Jumlah SKS \\
\hline Ekonomi Pembangunan & Agama & 2 \\
& Pancasila & 2 \\
& Kewiraan & 2 \\
& Ilmu Alamiah Dasar & 2 \\
& Ilmu Budaya Dasar & 2 \\
\hline
\end{tabular}

Dilihat dari tabel diatas maka dapat diketahui bahwa untuk ketiga jurusan memiliki mata kuliah dasar umum yang sama dan jumlah sks yang juga sama.

Tabel 3.

Daftar Mata Kuliah Keahlian Yang Memiliki Muatan Etika Pada Jurusan Akuntansi, Manajemen, Ekonomi Pembangunan

\begin{tabular}{llcc}
\hline \multicolumn{1}{c}{ Program Studi } & \multicolumn{1}{c}{ Mata Kuliah } & Jumlah SKS & Boleh Diambil Pada \\
\hline \multirow{3}{*}{ Akuntansi } & Etika Bisnis & 3 & Tahun ke-2/3 \\
& Akuntansi Keperilakuan & 3 & Tahun ke-2/3 \\
& Auditing 1 & 3 & Tahun ke-2/3 \\
& Auditing 2 & 3 & Tahun ke-2/3 \\
\hline \multirow{2}{*}{ Manajemen } & Etika Bisnis & 3 & Tahun ke-2/3 \\
& Pemasaran & 3 & Tahun ke - 3 \\
\hline \multirow{2}{*}{ Ekonomi Pembangunan } & \multicolumn{1}{c}{-} & - & - \\
\hline
\end{tabular}

Pada daftar mata kuliah keahlian yang memiliki muatan etika pada jurusan akuntansi, manajemen, ekonomi pembangunan diatas (tabel.2) diketahui bahwa hanya jurusan akuntansi dan jurusan manajemen memiliki mata kuliah khusus yang membahas etika bisnis. Dan pada beberapa mata kuliah jurusan akuntansi yaitu akuntansi keperilakuan, auditing 1, auditing 2 juga membahas etika pada bab-bab yang dipelajarinya. Sedangkan mata kuliah jurusan manajemen yang membahas etika pada bab yang dipelajarinya terdapat pada mata kuliah pemasaran.

\section{B. Uji Hipotesis}

Tabel berikut ini menunjukan hasil uji Anova :

Tabel 4

Hasil Uji Anova

\begin{tabular}{lcc}
\hline \multicolumn{1}{c}{ Values Spesifik } & F & Sig \\
\hline Individualitas & 10.341 & .000 \\
\hline Sosial & 13.450 & .000 \\
\hline Teoretis & 8.104 & .001 \\
\hline Estetis & 10.221 & .000 \\
\hline
\end{tabular}

Dari tabel hasil uji Anova diatas (tabel 3) diketahui bahwa untuk variabel values spesifik (individualitas) $\mathrm{F}$ hitung $=10.341>\mathrm{F}$ tabel $=3.10$ yang berarti Ho ditolak dan $\mathrm{Ha}$ diterima. Artinya bahwa terdapat perbedaan values spesifik (individualitas) antara mahasiswa akuntansi, manajemen, dan ekonomi pembangunan mengenai capable, self respect, ambitious, successful, healthy, honest, responsible, independent, meaning in life. 
Untuk variabel values spesifik (sosial) dapat dilihat bahwa F hitung $=10.341>\mathrm{F}$ tabel = 3.10 yang berarti Ho ditolak dan Ha diterima. Artinya bahwa terdapat perbedaan values spesifik (sosial) antara mahasiswa akuntansi, manajemen, dan ekonomi pembangunan terkait dengan self discipline, family security, wisdom, national security, true friendship.

Untuk variabel values spesifik (teoretis) dapat dilihat bahwa F hitung $=8.104>\mathrm{F}$ tabel = 3.10 yang berarti Ho ditolak dan Ha diterima. Artinya bahwa terdapat perbedaan values spesifik (teoretis) antara mahasiswa akuntansi, manajemen, dan ekonomi pembangunan mengenai obedient, clean, helpful, intelligent, forgiving, broadminded, loyal, moderate.

Sedangkan untuk variabel values spesifik (estetis) dapat dilihat bahwa $\mathrm{F}$ hitung $=$ $10.221>\mathrm{F}$ tabel $=3.10$, yang berarti Ho ditolak dan Ha diterima. Artinya bahwa terdapat perbedaan signifikan pada variabel values spesifik (estetis) antara mahasiswa akuntansi, menejemen, ekonomi pembangunan mengenai mature love, creativity, curious, dan a world of beauty.

Hasil penelitian untuk value individualitas, value sosial, dan value teoritis sama dengan hasil penelitian yang dilakukan oleh Fathonah (2004) terhadap mahasiswa akuntansi dan mahasiswa kedokteran pada Universitas Gadjah Mada. Dimana hasil penelitiannya menunjukan terdapat perbedaan value individualitas, value sosial, dan value teoritis. Sedangkan untuk value estetis memiliki hasil penelitian yang berbeda. Hal ini berbanding terbalik dengan hasil penelitian Suryaningsum, dkk (2005) yang dilakukan pada mahasiswa akuntansi dan mahasiswa teknik sipil di beberapa perguruan tinggi Yogyakarta. Dimana hasil penelitiannya menunjukan tidak ada perbedaan secara signifikan antara mahasiswa akuntansi dan teknik sipil dalam hal value individualitas, sosial, dan teoritis. Dan hanya pada nilai estetis antara mahasiswa akuntansi dan teknik sipil terdapat berbeda.

\section{SIMPULAN DAN SARAN}

\section{Simpulan}

Berdasarkan hasil pengujian, analisis dan pembahasan maka dapat disimpulkan bahwa terdapat perbedaan yang signifikan pada nilai individualitas, sosial, teoretis, estetis antara mahasiswa akuntansi, menejemen, ekonomi pembangunan. Perbedaan ini bisa saja disebabkan karena hanya program studi akuntansi yang paling banyak mengajarkan mata kuliah etika. Dibanding program studi manajemen dan ekonomi pembangunan. Walau demikian bukan berarti bahwa mahasiswa manajemen dan ekonomi pembangunan tidak lebih baik dari akuntansi, namun mengingat penting untuk menanamkan spesifik value pada mahasiswa maka mata kuliah yang mengajarkan tetang etika sebaiknya mulai dicanangkan.

\section{Saran}

Berdasarkan penelitian yang telah dilakukan, dan memperhatikan keterbatas dan hasil dari penelitian ini, maka peneliti menyarankan agar sampel dapat diperluas yaitu dengan menambahkan mahasiswa pada jurusan yang sama di universitas-universitas lainnya. Dengan adanya perbedaan pada values spesific pada ketiga jurusan ini menunjukan bahwa mata kuliah yang bermuatan etika sangatlah dibutuhkan, karena dapat mempengaruhi perilaku dan sifat dari mahasiswa ke tiga jurusan. Untuk itu perlu dilakukan reformasi kurikulum dan muatan materi perkuliahan agar value spesific lebih dapat ditanam dalam diri mahasiswa. 


\section{DAFTAR PUSTAKA}

Dewi, Ni Nyoman Sri Rahayu Trisna. 2019. "Perilaku Etis Mahasiswa Akuntansi Ditinjau dari Locus Of Control dan Love Of Money". Journal of Accounting Science. Vol.3. Issue.2.

Diahsari, Erita Yuliasesti. 2011. "Eksplorasi Nilai-Nilai Hidup Mahasiswa". ISSN:18582559. Proceeding PESAT, Vol.4

Fathona, Siti. 2004. "Perbedaan Spesifik Value Antara Mahasiswa Akuntansi dan Kedokteran : Studi Empiris Pada Universitas Gadjah Mada". Jurnal Ekonomi dan Bisnis Indonesia. Vol. 19, No. 1. 82-97

Fitriah, Elis Anisah. 2014. "Personal Value dan Internal Prolitical Efficacy Terhadap Partisipasi Politik Mahasiswa Pemilih Pemula”. Jurnal Ilmiah Psikologi Vol.1. No.2.

Giacomino, D., dan Akers, M. 1998. "An Examination of the Differences Between Personal Values and Value Types of Female and Male Accounting and Non Accounting Education 13 (3): 565-584.

Mannan, Audah. 2019. "Etika Komunikasi Interpersonal Mahasiswa Ilmu Komunikasi Fakultas Dakwah dan Komunikasi Kepada Dosen Melalui Smartphone”. Jurnal AqidahTa Vol. V. No. 1

Muslimah. 2016. "Etika Komunikasi Dalam Persfektif Islma”. Sosial budaya Vol. 13. No.2.

Suryaningsum, Sri; Heriningsih, Sucahy ;dan Aryani, Ketut. 2005. "PentingnyaPerbandingan Nilai-Nilai Spesifik Antara Mahasiswa Akuntansi dan Teknik Sipil”. Jurnal Akuntansi dan Investasi. Vol. 6, No. 1. 129-146

Santrock, J.W. 2007. "Remaja”. Erlangga. Jakarta.

Yusuf, H. M. and Anim, W. 2015. Analysis of Effect of Ethics Education and Love of Money Perception of Accounting Students in the Preparation of Financial Statements. Journal of Education and Vocational Research. 6. 